\title{
Prospecting the Future: Meeting the Challenges Posed by Climate Change
}

\author{
K.M. Valsamma
}

\begin{abstract}
The world population is increasing at the rate of 10,000 per hour and by $31^{\text {st }}$ of October, 2011 the sevenbillionth person will be born marking an extraordinary milestone in the history of the planet. The United Nation has predicted that by 2050 the population of this planet will be 9.3 billion. For a planet which is already strapped for resources, as Roger Martin the chair of the NGO "population Matters "wrote in the Guardian, the birth of the 7 billionth person is "a sobering reminder of the planet's predicament". Echoing the same sentiment the TIME magazine has now come out with an article which states that "the real victim of the over population will be the environment". All this boils down to the simple fact that the physical resource of the planet is "finite". In the "Limits to Growth" Meadows et al had precisely underscored this finite nature of the Earth.They had also warned the world that we are about to reach an "overshoot and collapse scenario". The figures in respect of the components of ambient concentration of green house gas as they existed before 1750 and during 2006 serves to compare and contrast not only the warming effect of $\mathrm{CO}_{2}$ but also the health hazards posed by particulate matter. As per the estimate of World Health Organization 800,000 people fall prey to premature death [1] due to the intake of polluted air containing, Particulate Matter of the size of 21 to 70 microgram per cubic meter..The abysmal air quality of the Indian cities is symptomatic of the environmental degradation, requiring corrective action by policy decisions at the level of the Govt. World Bank has characterized India's pollution induced warming as both "growth related" and "poverty related". The impacts of climate are invasive. It is not merely confined to extended dry periods, increased frequency of heavy precipitation, or microbial population of the macroenvironment. The specter of toxic Algae blooms, and zoonotic diseases are in sight. Add to this worry of the toxic algalblooms accumulated in the filter-feeder-bivalves, getting transferred to human beings. The review underpins that there is a need for putting in yeoman's effort based on "One health" concept which stands for the health of humans, animals and the environment, because there is only "one health" in our entire ecosystem
\end{abstract}

Keywords--- PM $M_{10}$, Emissions, Shift in Technology, Air Quality, Particulate Matter

K.M. Valsamma, Kerala Agricultural University, Kelappaji College of Agricultural Engineering and Technology, Tavanur. E-mail: valsammakm@gmail.com

\section{INTRODUCTION}

$\mathrm{T}$ HE world scientific community at large is progressively coming round to a consensus [2] on the science of global warming. In the final analysis a warming world is not any more a "Green delusion" [3] or a distant thing into the future, but an "unequivocal" truth [4] closing in on us from all sides (US Global change Research Program). After a rambling overview of the global warming scenario showing the interplay of the ecological factors involved, the paper traverses through the impacts of climate change which hold out the threat of species extinction and bio diversity bringing in its remit also the threats to the extremophiles of the Arctic region. In the sub heading "Health Implication" the author catalogues the impact of the imponderables triggered by pesticides by starting to recount the scenario from "Silent Spring". The author delineates how cultivation of chilli enables disintegration of pesticide residues in the natural way. The recent report of WHO about the abysmal air quality in the cities and the health concern posed by Particulate matter with reference to the reported air quality of some of the Indian cities including the Capital Delhi comes in for discussion. The concluding section summarizes, the above thinking that boils down to a finding that there is only one "common future" for all of us and also for our next generation. To that end the future has to be engineered keeping in mind the health of the individual means also the health of the planet and the health of animals that inhabit it in furtherance of the "one health concept.

\section{Climate: An Overview}

The emission from human activities is reshaping the carbon cycle. The climate history shows how the changing levels of Green House Gases and temperature had shaped the climate from time immemorial. Though there is a precedent of Global Warming in the 4.5 billion years history of the earth, as evidenced by the Eocene Epoch that lasted from 55 million to 38 million years ago, when the atmospheric concentration was about $500 \mathrm{ppm}$, with the sea level some 100 meters higher than today, there was one marked difference: unlike now, it was all due to sustained increase in $\mathrm{CO}_{2}$ that was released from volcanoes over tens of millions of years. During the Eocene Epoch, the shift in the climate had actually occurred over a period of millions of years, so that whatever living organisms were there had enough time to adapt themselves to the warming climate. There are scientists who believe that there are some unrecognized feed backs in the climate system involving types of clouds that only form when $\mathrm{CO}_{2}$ levels are very high and that our knowledge about this is either very limited or nil. Reconstruction of the Eocene like atmosphere in the climate models had not shown much warming, as the 
unrecognized feed backs involving clouds that might have existed at the appropriate time in the Eocene epoch, had not been factored into the computer modeling. This is the basis for concluding that if an Eocene like climate were to reenact this time, with the level the atmospheric $\mathrm{CO}_{2}$ doubling in the next two or three decades over the pre-industrial figures of $280 \mathrm{ppm}$, it will be both swift and very abrupt. The global climate system is supposedly loaded with irreversible tipping points which are exacerbated by emissions [5].

\section{Global WARMing VERSUS BIODIVERSITY}

The quintessence of what is slowly but surely unfolding before our eyes is that the planet is on the brink of a disaster, standing in danger of losing much of the rich bio diversity, combined with a more serious threat of species extinction, as varied and diverse as some of the extremophiles: "populations of bacteria living in spumes of thermal vents" on the ocean floor, that multiply in water above the boiling point to the "subsurface litho autotrophic microbial ecosystem," [ 6 ] living beneath earth's surface at a depth of 2 miles. The very thought of a complete glacial meltdown sends shivers down the spine of people living in low lying areas. It is on record that Arctic ice is, now reduced to an extent of 1.67 million square miles from what was once a massive expanse of 2.59 million square miles.[7] This is extremely important, since the ice caps are to the ecology what a canary is to the coalmine. More over, Arctic, is the home to rare species like extremophiles, where the living creatures have the physiological adaptability to live in the most frigid waters of Arctic by keeping their blood in fluid condition, by what is called biochemical antifreeze. On the other hand what is happening in the Himalayas is equally appalling. As a result of the constant glacial melt caused by global warming, more and more lakes of the like of Imja Glacier Lake are getting formed. Places in the vicinity of Himalayas, are actually becoming "danger zones" or death traps in the making, with the prospect of high altitude glacial debris, known as moraine, having the potential to release a huge deluge of water, mud and rock up to a height of 13 meters, swamping homes and fields located as far and wide as 100 . $\mathrm{km}$, leading to total loss of land for a generation looming large.[8]. One can only shudder at the consequences of a full scale melt of these mountain glaciers. American Biologistconservationist and the two time Pulitzer prize winner E.O Wilson speaking on biodiversity had pertinently remarked that "genes hold cultures on a leash" [9] and hence the greatest peril that can befall on this planet is not "energy depletion, economic collapse" or even "a limited nuclear war", the worst effects of which can be warded off and repaired within a few generations, but the one "that will take millions of years to correct is the loss of genetic and species diversity by the destruction of natural habitats".

\section{HEALTH IMPLICATIONS}

Just as there was a wave of nascent environmentalism which still lingers unabated, when the classic book "Silent spring", depicting in vivid and harrowing details, how pesticides "still the songs of the birds, and leaping of fish in the streams, with a deadly film, and to linger on in soil -all this though the intended target may be only a few weeds or insects"[10], was released, there is a growing awareness all round about the dangers posed by pesticides. They pollute significant areas of our air and water, and blot out some of the already endangered species from the earth, not before exposing the farm workers, the women of reproductive age and children to toxic levels beyond tolerance. TIME magazine had reported the predicament in the Southern states of US, when fire ants were fought with pesticides. There was such widespread harm to other creatures, that "the beneficiaries cried for mercy". In another instance there was furore across the entire country over spraying Cranberry plants with aminotriazole consequent to which the US Agriculture Department had clamped a ban against Cranberry marketing. Whereas more than 2 billion pounds of pesticides are used in the US the quantity of pesticides used in India is of the order of $60000 \mathrm{MT}$ of pesticides for raising vegetables in 5.12 million ha of land [11] Experiments have shown that coriander and chili plants have the ability to absorb $\mathrm{HCH}$ residues from the soil while at the same preventing leaching to the ground water. Hence cultivation of Chili is being regarded as a redeeming technology in agricultural and horticultural practices both for removing pesticide from the contaminated soil and also for degrading the pesticides in the vegetative plant body. [12, 13] In developing countries such as India and China apart from pesticide pollution, the air is heavily polluted. The figures in respect of the components of ambient concentration of green house gas as they existed before 1750 and during 2006 serve to compare and contrast not only the warming effect of $\mathrm{CO}_{2}$ but also the health hazards posed by particulate matter. The atmospheric composition of the components such as of $\mathrm{CO}_{2}, \mathrm{CH}_{4}, \mathrm{O}_{3}, \mathrm{SF}_{6}$ etc during the preindustrial (prior to 1750) period and 2006 and the resident time, each gas remains in the atmosphere are tabulated below:[Table 1]

As per the estimate of World Health Organization 800,000 people fall prey to premature death [1] due to the intake of polluted air containing, Particulate Matter of the size of 21 to 70 microgram per cubic meter. Now the WHO has still lowered the benchmark size to 15 microgram per cubic meter which safety norm does not square with even the norm now in vogue for the US. PM are complex mixture of solid and liquid particles of organic and inorganic substance suspended in the air (WHO September 2011). As of now, as per epidemiological studies, the relationship between air pollution and health hazards known as Concentration Response Function stands fairly well accepted. Constituent components from the emissions such as ground level ozone (tropospheric ozone) $\mathrm{N}$-Oxides and $\mathrm{CO}_{2}$ etc are especially very harmful. The above table shows that except for ozone, the resident time of the rest of the components is comparatively longer. This makes the health hazard all the more vexing. City dwelling Indians are admittedly exposed to higher risk of respiratory illness, heart disease and lung cancer because the concentration in the air is way above the guidelines prescribed by the WHO. 
Table 1: Comparison of Ambient Concentration of GHGs Prior to 1750 and now [2006]

\begin{tabular}{|c|c|c|c|c|}
\hline Gas & $\begin{array}{c}\text { Pre-1750 } \\
\text { concentration }\end{array}$ & $\begin{array}{c}\text { Current } \\
\text { tropospheric } \\
\text { concentration }\end{array}$ & $\begin{array}{c}\text { Atmospheric } \\
\text { Residence } \\
\text { time(years) }\end{array}$ & $\begin{array}{c}\text { Increased radiative } \\
\text { forcing[watts/meter }\end{array}$ \\
\hline $\mathrm{CO}_{2}$ & $280 \mathrm{ppm}$ & $377.3 \quad \mathrm{ppm}$ & Upto 200yrs & 1.66 \\
\hline N.Oxide $\left(\mathrm{N}_{2} \mathrm{O}\right)$ & 270 & $318-319 \mathrm{ppb}$ & 114 & 0.16 \\
\hline Methane $\left(\mathrm{CH}_{4}\right)$ & $688-730 \mathrm{ppb}$ & $1730-1847 \mathrm{ppb}$ & 12 & 0.5 \\
\hline $\begin{array}{c}\text { Tropospheric } \\
\text { Ozone }\left(\mathrm{O}_{3}\right)\end{array}$ & 25 & 34 & Hrs to days & 0.35 \\
\hline $\begin{array}{c}\text { Industrisal } \\
\text { gases[HFC/PFC/ } \\
\text { halons] }\end{array}$ & 0 & $\begin{array}{c}\text { Upto 545 parts } \\
\text { per } \\
\text { trillion }\end{array}$ & $\begin{array}{c}\text { Between 5 and } \\
260 \text { years }\end{array}$ & $\begin{array}{c}0.34 \text { for all halocarbons } \\
\text { collectively }\end{array}$ \\
\hline $\begin{array}{c}\text { Sulfur } \\
\text { Hexafluoride }\left(\mathrm{SF}_{6}\right)\end{array}$ & 0 & $\begin{array}{c}5.22 \text { parts per } \\
\text { trillion }\end{array}$ & 3200 & 0.002 \\
\hline
\end{tabular}

Source: Adapted from T.J.Blasing; Karmen Smith,/CO $\mathrm{C}_{2}$ information Analysis Oak Ridge National Laboratory,July 2006.htt://cdiac.esd.ornl..gov/pns/current_ghg.

The data of particulate matter in respect of a variant PM 10 (measuring 10 micrometers or less) for 33 Indian cities including Ludhiana ,Kanpur, Delhi, Luck now, Indore and Agra etc are exceedingly high and staggering obviously above the WHO norms. These particles enter the blood stream through the lungs with grave consequences for health. The abysmal air quality of the Indian cities is symptomatic of the environmental degradation, requiring corrective action by policy decisions at the level of the Govt. It appears that the author of the "A Journey in the other world" John Astor had anticipated quality degradation of air that might occur in future, when we find that in his book, a science fiction there is a reference to a price that we have to pay for even air. Further there is a description of attempted "axis straightening" of the earth as a solution for making the climate, universally benign. As per the Central Pollution Control Board [PCB] list of polluting industries, the Aluminum, sugar, Paper, Pharmaceuticals, Petrochemicals, Leather, Refineries and pesticides are on the top of the list and figure up as major-red category- polluting industries. World Bank has characterized India's pollution induced warming as both "growth related" and "poverty related". Arguably the World Bank's finding mirrors the country's size and diversity as well as India's low income and middle income economy. The deteriorating urban environment, increasing industrial waste and chemical pollution are evaluated as the outcome of growth.

\section{FOOD SAFETY IMPACTS}

Climate change is known to be contributing both to the direct and indirect impacts affecting food safety concerns at all the stages of the food chain. The emerging safety hazards that emanate from climate change are so many that they brook no delay in addressing them. Projection for the $21^{\text {st }}$ century shows that global warming will accelerate with predictions of the average increase in global temperature ranging from $1.8^{\circ} \mathrm{C}$ to $4^{\circ} \mathrm{C}$ [14] but also include trends towards stronger storm systems, increased frequency of heavy rainfalls and extended dry spells. It is widely understood that the risks of global climate change occurring as a consequence of human behaviour are inequitably distributed, since whereas most of the actions causing climate change originate from the developed world, it is instead the less developed world that is bearing the brunt of the public health burden [15]. There might be fall in food crops to the extent the rain falls short of the optimum needed. Similarly the crops are put to a great stress and disadvantage by extremities like drought and flood. It has been shown that when shoot inhibitor herbicides like alachlor (Lasso, Micro-Tech), metolachlor (Dual II), acetochlor(Surpass, TopNotch, Harness), dimethenamid (Frontier), EPTC (Eradicane), are applied, direct injury to the crop occurs as the crop is under additional stress and under conditions favorable for rapid herbicide uptake Hall et al., 2002; Rose et al., 2001 have posited that the link between the seasonality of the outbreak and the temperature attributes and climatic variation acting as a contributory factor to the disease are clearly documented. Climate accentuates the range of infectious diseases, while weather, which is impacted by climate, affects the timing and intensity of outbreaks [16]. Increases in salmonellosis and to a lesser extent campylobacteriosis (Kovats et al., 2005) are invariably preceded by rise in temperature. Hall et al., 2002 [17] had found that the incidence of disease had increased in proportion to the decease in latitude which had shown that the outbreak was severe in areas near to the equator and less severe in Polar Regions. Exposure of livestock to excessive heat and humidity predispose livestock to diseases such as mastitis which is exacerbated when milk of cows with sub clinical mastitis enters the food chain as a result of incomplete pasteurization or when milk is consumed in the raw form without bringing the milk to boil [18]. Between 1997 and 2004 in the US there was disease outbreak consequent to the consumption of oyster harvested from Alaska and Pacific Northwest [19]. It is widely understood that acidification causes changes in Harmful Algal Blooms (HAB) dynamics through changes in phytoplankton. On the whole the health of the human beings is the health of the plannet, its environment and the health of livestock, on the principle of the concept of "one health".

\section{CONCLUSION}

The focal point that had come in for discussion, with in the remit of this paper is the ripple effect of the Climate change, running through the whole planet, touching upon the entire 
gamut of human life and existence on earth which is why Brundtland Report a groundbreaking UN Study, which forms the cornerstone of all futuristic sustainable planning, is captioned as "Our Common Future". As to the target of feeding the teeming millions and fighting the pesticide problem and pollution affecting human being leading to health hazards, it is found that ,biotechnology /Nanotechnology combine offers instant solutions by putting in place, the convergence of various branches of science by opening up new vistas , and presenting us with a suite of technologies as varied and diverse as GMO foods, Carbon nano tubes, sensor telemetry to in-vitro meat production [20] where it is possible in the livestock sector to have all the goodness of nutritious meat, by tissue engineering without ever killing a cow and where it is possible to cultivate pest resistant and drought resistant plants towards growing more crop from each drop, as they call it.

\section{REFERENCES}

[1] Cohen R. Anderson, B. Ostro, K.D. Pandey, M. Krzyzanowski, N. Kunzli, K. Gutschmidt, A. Pope, I.Romieu, J. Samet and K. Smith.. "Mortality Impacts of Particulate Air Pollution in the Urban Environment", in M. Ezzati, A.D. Lopez, A.D. Rodgers and C.J.L. Murray, ed., Comparative Quantification of Health Risks: Global and Regional Burden of Disease due to Selected Major Risk Factors. Geneva: World Health Organization, 2003.

[2] Oreskes N, "Beyond the ivory Tower: The Scientific Consensus on ClimateChange", Science 306:1686, 2004.

[3] Martin W. Lewis, Green Delusions, "An Environmentalist Critique of Radical Environmentalism”, ISBN-13: 978-0822314745, 1993.

[4] Rosenthal Elisabeth, Revkin Andrew C, "Science Panel Calls global Warming Unequivocal", New York Times, 2007.

[5] CAETS: Environment and sustainable Growth :A statement by CAETS [Council of Academies of engineering and Technological Science] 2007.

[6] Edward O. Wilson, "Vanishing Before Our Eyes", TIME, 26.April 2000

[7] James: http://empowerenews.net, 2011.

[8] Suzanne Golden Berg, Glacier Lakes, "Growing danger zones in the Himalayas", Guardian News Paper Limited, 2011.

[9] Edward O. Wilson, "On Human Nature", ISBN-13: 978-0674634428, Pp. 167, 1978.

[10] Rachel Carson, "Silent Spring: The obligation to Endure", Pp. 7, 1962

[11] Karanth N.G.K, Deo P.G, Veena Nadig N.K, "Microbial production of bio surfactants and their importance", Curr. Sci. 77(1): Pp. 116-126, 1999b.

[12] Karanth N.G.K, Jayaram M, Majumder S.K, "Insecticidal residue invegetables obtained from soil treated with hexachlorocyclohexane", J. Food. Sci. technol., 19, Pp. 14-19, 1982.

[13] Karanth N.G.K, Jayaram M, Majumder S.K, “ Observations on the growth and residue levels of insecticide in vegetable plants raised on hexachlorocyclohexane treated soil", Comp. Physiol. Ecol. 8(4), Pp. 357-361, 1983.

[14] IPCC (Intergovernmental Panel on Climate Change), "Summary for Policymakers", InClimate Change 2007: Impacts, Adaptation and vulnerability. Contribution ofWorking Group II to the Fourth Assessment Report of the Intergovernmental Panel onClimate Change, M.L. Parry, O.F. Canziani, J.P. Palutikot, P.J. van der Linden, and C.E. Hanson, eds. Cambridge, UK: Cambridge University Press, 2007.

[15] Campbell-Lendrum D, Corvalan C, Neira M Global climate change: implications for international public health policy. Bull. WHO 85: Pp. 235-237, 2007.

[16] Epstein PR, "Climate change and emerging infectious diseases", Microbes Infect. 3: Pp. 747-754, 2001.

[17] Hall GV, D'Souza RM, Kirk MD, "Foodborne disease in the new millennium: out of the frying pan and into the fire", Med. J. Aust. 177: Pp. 614-618, 2002

[18] Hameed KGA, Sender G, Korwin-Kossakowska A, "Public health hazard due to mastitis in dairy cows", Animal Science Papers and Reports. Vol. 25 , No. 2, 2006.
[19] Drake S L, DePaola A, Jaykus L, "An Overview of Vibrio vulnificus and Vibrio parahaemolyticus", Comp. Rev. Food Sci. 6: Pp. 120-144, 2007.

[20] Edelman, P.D M.Sc. D.C. McFarland, Ph.D. V.A. Mironov, Ph.D., M.D. and J.G. Matheny, M.P.H, "In vitro cultured meat Production" Tissue Engineering, Vol.11, No. 5/6, 2005 @ Mary Ann Liebert, Inc 
